\title{
EDITORIAL
}

\section{Tobacco and the Soldier}

THE paper by Crowdy and Gould which appears in this issue marks an important stage in their prospective study of the smoking habits of the British soldier.

The potential sequelae of smoking, especially cigarette smoking, are now firmly substantiated and, with the current practice of the dissemination of medical knowledge through a variety of mass media, the layman can reasonably be expected to be well informed on this subject and to base his actions accordingly. The continuing effectiveness of such applied psychology, however, depends largely on corrobation of existing evidence, further research, and, dependent on the results of these, the sowing of fresh seeds in the field of health education.

That diligence in such research is not lacking, and that hazards additional to carcinoma of the lung, chronic bronchitis, and coronary heart disease must now be taken into consideration, is made clear in the Lancet (Annotation, 1969). Reference is made therein to work describing the effect of cigarette smoking on the reduction of skeletal muscle tone in spastic patients, and to the degree of depression of the patella reflex of young men, relative to the nicotine content of cigarettes smoked. Perhaps even furtherreaching are the possible hazards to the foetus, consequent upon the effects of cigarette smoking on the enzyme activity of the placenta. There is clearly a long way to go before 'finis' can be written to this particular chapter.

Against this background it is of some interest to look over the past eighty years or so at the attitudes which have been adopted towards the soldier and his smoking. In "The Soldier's Pocket Book for Field Service", General the Viscount Wolseley (1886) recommended that one pound each of tobacco and soap per man per month should be issued "like all other rations". Clearly, there was no question of smoking being regarded as a harmful practice. Less than thirty years later, however, it would appear that certain doubts must have been expressed, as the Lancet gave space to an Annotation (1914) of considerable length which opened with "We must surely brush aside much prejudice against the use of tobacco when one considers what a source of comfort it is to the sailor and soldier engaged in a nerve-wracking campaign." While being careful to make it clear that the habit of smoking should not include "over indulgence and self-poisoning" it concluded that "the hope is thoroughly justified that the soldier in the present campaign will be generously supplied with this indisputable creature comfort."

During the more recent world conflict, the British Medical Journal, in Medical Notes in Parliament (1942) reported a deliberation in the House on a proposed increase in tobacco duties, and on the desirability or otherwise of members of the Forces bearing their share of the increased rates. Medical evidence was adduced and hardening of medical opinion on the potential evils of tobacco is apparent. Although, subsequent to the debate, the serviceman at home was required to bear his share of tobacco duty to the same extent as the civilian, a free issue of cigarettes continued in theatres of war. (It is, perhaps, for consideration whether the quality and content of at least certain of the brands issued - one designated by a single letter of the alphabet comes particularly to mind-might have formed part of a cunningly-designed aversion therapy, but this is purely conjectural). 
Adam and Ladell (1953) who conducted field studies on troops of the Commonwealth Division in Korea during the winter of 1951-52 included some observations on smoking habits in their report. Arising from these and from a study of the literature, they put forward the need for further work to be carried out to determine whether the smoking habits of men who have to live and fight in extreme cold need to be modified in order to lessen the pre-disposition to cold injury resulting from peripheral vasoconstriction. They also noted that a number of men on sentry duty were heard to cough at intervals, and on questioning these men it seemed that the coughs might be due to smoking. Medical advice to Commanders on hazards to life and limb is undoubtedly more acceptable the more imminent these hazards are, or appear to be. Here, surely is such a situation, in which the immediate requirement is the maximum avoidance of loss of manpower, whether from cold injury or consequent on an unneccessary alerting of the enemy.

Long-term effects are much more difficult to convey. Nevertheless, the findings of Crowdy and Gould that the R.A.M.C. group of their subjects showed the highest percentage of non-smokers, the lowest proportion of cigarette smokers, and in the latter, a relatively low daily consumption rate are decidedly encouraging. It would be disappointing, to say the least, if the Corps which must constitute the mainspring of health education in the Army were to show up otherwise.

\section{REFERENCES}

ADAM, J. M. and LADELL, W. S. S. (1953). Report of Field Studies on Troops of the Commonwealth Division in Korea-Winter 1951-52. Unpublished, War Office, London.

Annotation (1914), Lancet ii, 857.

ANNOTATION (1969) Lancet i, 1013.

Medical Notes in Parliament (1942), Brit. med. J. i, 598.

WoLSELEY, General The Viscount (1886). The Soldier's Pocket Book for Field Service, p99. Macmillan, London.

\section{Cervical Smears}

IN this issue of the Journal, Glen gives his views on the place of cervical smears in his practice as a General Duties Medical Officer. There is still considerable controversy as to the usefulness of this investigation, particularly whether early detection of carcinoma in situ and its subsequent treatment has reduced the mortality from the disease.

The problem has been the subject of leading articles in the Lancet (1969) and British Medical Journal (1969) earlier this year. The British Journal of Hospital Medicine (1969) devoted several articles to carcinoma of the cervix in its May issue (Bate, J. G., Coppleson, M., Cox, B.S., Hughes, J. and Arwyn Evans, M.D., and Way, S.).

Glen asks two important questions: "Who should take the smears and who should examine them ?' In October 1967 the Army Histopathology Registry (AHR) made its Cervical Cytology Screening Service (founded in 1962) available to all service family doctors and the previous age limit restrictions confining the service to women aged thirty-five and over, was also removed. By the end of 1968 the number of slides being examined annually had risen to 14,512 . The figure for 1965 was 6,789 and during 1969 the number continues to rise $(9,400$ in the first six months). 
The considerable increase in the number of requests for cytological examination has created several problems. Cytology is not an exact science; Coppleson and Reid (1967) claimed 93 per cent accuracy. Screening is a tiring and tedious job, usually performed by laboratory technicians trained in cytology, girls trained only in cytology and in some Centres by trained nurses. The efficiency of the already limited numbers of screeners deteriorates unless the number of slides seen per day is limited. A further variable is the experience of an the interpretation by the pathologist who is responsible for the final report.

Automated and semi-automated screening devices are becoming available and the Department of Health and Social Security has initiated several trials into their usefulness and accuracy. One of these machines, the Vickers Cytology Screening Apparatus, identifies suspicious cells and clumps of cells on a moving film, marks their position and can later automatically display them to the cytologist. Such devices must improve the service available, but again cannot give one hundred per cent accuracy.

Suspicious cases must be reviewed using a combination of techniques such as colposcopy and Schiller's test combined with repeat cytology. Coppleson and Reid (1967) obtained 92 per cent accurate diagnosis with colposcopy as against 93 per cent with cytology, but in combination the two gave a diagnostic accuracy of 98 per cent. Cone biopsy can provide the only really reliable method of diagnosis and in the case of dysplasia and carcinoma-in-situ will also provide curative treatment in the majority of instances where the process is restricted to the cervix.

Finally, who should take the smear? It has been shown by Fidler, Boyes and Worth (1968) in several studies in this country that those at greatest risk, the lower socioeconomic groups, are the slowest to make use of a cytological screening service. As Glen points out, we in the Services are in an enviable position. Our patients tend to be more "manageable". Nevertheless many women, particularly in this group, dislike intimate examination by a male medical officer.

In the Services we are fortunate in having to assist us a number of highly trained and experienced S.S.A.F.A. nursing sisters. Glen suggests that use could be made of these ladies in persuading the reluctant patients to come forward for screening. Why not go even further and allow them to take the smears in the patient's own home?

\section{REFERENCES}

BATE, J. G. (1969). Brit. J. hosp. Med. 2, No. 5

Coppleson, M. (1969). Brit. J. hosp. Med. 2, No. 5.

Coppleson, J. V. N. and ReiD, B. L. (1967). Preclinical Carcinoma of the Cervix Uteri. Pergamon Press. Oxford.

Cox, B. S. (1969). Brit. J. hosp. Med. 2, No. 5.

FIDLER, H. K., Boyes, D. A. and WorTH, A. J. (1968). J. Obstet. Gynaec. Brit. Cwlth 75, 392.

HugheS, J. and ARWYN Evans, M. D. (1969). Brit. J. hosp. Med. 2, No. 5.

Leading Article (1969). Lancet i, 927.

Leading Article (1969). Brit. med. J. ii, 585.

WAY, S. (1969). Brit. J. hosp. Med. 2, No. 5.

\section{From the Birthday Honours List}

K.B.E. Lieutenant-General N. G. G. TALBOT, O.B.E., T.D., Q.H.S., M.D., F.R.C.O.G. C.B.E. Colonel S. CURWEN, T.D., M.R.C.S., L.R.C.P., D.M.R.T.

M.B.E. Captain J. R. H. GIBBONS, T.D., M.B., Ch.B., F.R.C.S., F.R.C.S. (Edin.). 